\title{
Body condition and physiological changes in male green turtles during breeding
}

\author{
Tim S. Jessop ${ }^{1, *}$, Mark Hamann ${ }^{2}$, Colin J. Limpus ${ }^{3}$ \\ ${ }^{1}$ Center for Reproduction of Endangered Species, Zoological Society of San Diego, San Diego, California 92112, USA \\ ${ }^{2}$ Queensland Parks and Wildlife Service, PO Box 1735, Bundaberg, Queensland 4670, Australia \\ ${ }^{3}$ Department of Environment, PO Box 155, Brisbane, Queensland 4002, Australia
}

\begin{abstract}
Investigations were made into the body condition, energy metabolite and endocrinal changes of male green turtles Chelonia mydas prior to and during their vernal breeding period in the southern Great Barrier Reef. Prior to migration, breeding males exhibited a higher body condition index than non-breeding males. However, during the migratory reproductive period, breeding males lost significant body condition. Concurrent with these physical changes, breeding males showed a reduction in plasma triglycerides and an increased level of total protein towards the mid- to late breeding period. The plasma steroids corticosterone and testosterone increased and decreased, respectively, during the migratory/breeding phase. The pattern of change in body condition and physiology allude to a high-activity fasting period during the migratory/breeding phase of the male green turtle's life history. These marked physiological events during breeding suggest a proximate basis for terminating seasonal reproductive events, and a potential basis for phenotypic variation in male reproductive tactics.
\end{abstract}

KEY WORDS: Chelonia mydas $\cdot$ Male green turtle $\cdot$ Reproduction $\cdot$ Energy requirements $\cdot$ Physiological changes

Resale or republication not permitted without written consent of the publisher

\section{INTRODUCTION}

A large meta-population of green turtles reside in, or migrate to, the coastal waters off the east coast of Queensland, in Northern Australia (Chaloupka \& Limpus 2001). Here, green turtles inhabit the coastal seagrass meadows or the coral reefs of the Great Barrier Reef (Limpus \& Reed 1985, Limpus 1993, Limpus et al. 1994, Cogger 1996). The green turtle meta-population can be divided into 2 breeding units, one confined to the northern and one to the southern Great Barrier Reef (Norman et al. 1994). To access such reproductive areas, male green turtles, like females, may be required to undertake migratory swimming activities ranging from <10 to $1443 \mathrm{~km}$ (Limpus 1993). Migration distances vary depending on the location of the male's resident feeding ground relative to these 2 breeding units. In between their arrival and departure migrations, male turtles undertake a 2 to 3 mo period of reproductive activities, comprised of energetically demanding reproductive behaviors (Booth \& Peters 1972, Jessop et al. 1999b). Male turtles breeding in the southern Great Barrier Reef typically begin reproductive activities after aggregating in the lagoons and reefs in early September. These focal breeding sites house reproductive activities that peak in early October and slowly decline until late November before the onset of the return migration.

During the long combined migration/breeding period, it is presumed that male green turtles, like most vertebrates that undertake similar life-history phenomena, rely on previously accumulated energy reserves (Cherel et al. 1988a, Bauchinger \& Biebach 1998, Jenni \& Jenni-Eiermann 1998). Consequently, it would be expected that such energetically demanding activities, coupled with extended periods of limited or no feeding, could result in conspicuous body condition, energy metabolite, and endocrine changes in breeding males. 
We report investigations into these 3 aspects of their physiology during breeding.

First we examined changes in body condition during the migratory and breeding phases of male green turtle reproduction. Males must accumulate significant energy reserves prior to migration for use during the migratory/breeding period so they can reach their breeding grounds and still be able to conduct scramble competition, an energetically demanding mate searching process (Jessop et al. 1999b). However, having once undertaken the migratory reproductive phase, breeding males are thought to lose body condition, suggesting a negative energy balance due to both a marked reduction in feeding and high energetic costs associated with migration and breeding activities. To determine whether such a change in body condition was evident in males, we compared differences in body condition between breeding and non-breeding adult males during this period. This comparison would indicate the magnitude of change in body condition of breeding males both prior to the start, and until towards the end, of breeding activities.

We wanted to address the question regarding where male turtles get the energy for migration and breeding. In migrating birds, accumulated fat stores provide the main fuel for flight, with proteins being catabolised during prolonged flight and extended periods of fasting (Cherel et al. 1988a,b,c, Belkhou et al. 1991, Bauchinger \& Biebach 1998, Jenni \& Jenni-Eiermann 1998). In mammals, birds, and female green sea turtles, transitions in energy sourcing generally involve a switch from predominantly lipid to predominantly protein-reliant energy metabolism (Cherel et al. 1988a, Belkhou et al. 1991, Hamann et al. 2002a,b). Male green turtles making similar energetic commitments might also undergo distinct metabolic shifts in energy substrates at different stages in their migratory or breeding activities. To investigate this, we measured changes in the plasma levels of triglycerides and total protein of breeding male turtles, and used them as indices of lipid and protein metabolism.

We also wanted to look at what hormones are important to male green turtles during migration and breeding. Several types of hormones are implicated in the regulation of physiological processes during migratory and fasting events (Wingfield et al. 1990, Ortiz et al. 2003). The adrenal steroid corticosterone has been widely implicated in regulating a number of metabolic events associated with migration and fasting in vertebrates (Cheral et al. 1988a, Jenni et al. 2000, Piersma et al. 2000, Landys-Ciannelli et al. 2002). Plasma levels of corticosterone appear to be increased during migration and towards the end of fasting periods in vertebrates. We measured levels of corticosterone and testosterone, another steroid hormone, to see whether similar patterns of cor- ticosterone release take place in males during their migratory/breeding period. This allowed us to determine whether males displayed endocrine patterns correlated with broader body condition and metabolic changes during the migratory/breeding period.

\section{MATERIALS AND METHODS}

Field protocol. Male green turtles were sampled from coral reefs adjacent to Heron Island $\left(23^{\circ} 26^{\prime} \mathrm{S}\right.$; $\left.151^{\circ} 57^{\prime} \mathrm{E}\right)$. This site was sampled 6 times between 1996 and 1998, for 2 to $3 \mathrm{wk}$ periods, 3 times in August and 3 times from mid-October to early November. The August trips coincided with the time when resident adult males were breeding and were in the final phases of preparation for migration and breeding activities. During the 3 October/November trips, breeding males actively participating in courtship activities were sampled.

Swimming turtles were captured by hand after diving onto them from purpose built turtle-catch boats (Limpus \& Reed 1985). Laparoscopic examination was used to determine whether male turtles were sexually mature, based on the presence of a differentiated mature testis. As male green turtles generally breed less than annually (Limpus 1993), adult males were further classified into non-breeding and breeding cohorts, depending on their reproductive status for the upcoming breeding season, following the methods of Limpus \& Reed (1985). Throughout the year, adult males were classified as non-breeding if they possessed a cylindrical testis and associated pendulous epididymis, without evidence of sperm production or sperm storage. Breeding males, i.e. those preparing to breed for the upcoming season, possessed distended seminiferous tubules in the testis, and the duct of the epididymis was engorged with spermatozoa. Breeding males captured during the breeding season often bore damage indicative of courtship participation, including abrasions to the trailing edge of the front and hind flippers.

Determination of body condition index. Male turtles that were brought back to shore $(\sim 30 \%$ of all males captured) were weighed on a Salter scale to the nearest $0.5 \mathrm{~kg}$ and their curved carapace length (CCL) was measured to the nearest $1 \mathrm{~mm}$ with a fibreglass tape. In this study, male body mass ranged between 74.0 and $177.0 \mathrm{~kg}$, and CCL ranged between 88.4 and $111.1 \mathrm{~cm}$. Body condition was defined as the residual of the regression of body mass on CCL (mass $=1 /[-0.047+$ $\left.\left.-0.002 \times \mathrm{CCL}^{0.609}\right]\right)$. A positive residual indicated an above average mass for a given CCL and a negative residual signified below-average condition.

Blood sampling protocol. Immediately following capture, turtles were hauled into the catch boat and a 
1 to $2 \mathrm{ml}$ blood sample was taken from the dorsal cervical sinus using a 21 gauge $\times 38.1 \mathrm{~mm}$ needle and a $5 \mathrm{ml}$ syringe. Blood was immediately transferred into a heparinized tube and placed on ice, prior to centrifugation $(1120 \times g)$, for $5 \mathrm{~min}$. Plasma was stored in liquid nitrogen. Turtles were not sampled if the time between chasing and capture exceeded $5 \mathrm{~min}$, to prevent the possibility of stress-related changes in corticosterone and testosterone levels (Jessop et al. 2002).

Measurement of plasma metabolites. Plasma was analyzed for triglycerides (= total glycerol) using spectrophotometry (Sigma procedure 320-UV). Briefly, $0.2 \mathrm{ml}$ of sample (in duplicate) was added to $0.5 \mathrm{ml}$ of ethanol $(95 \%)$ and incubated at $60^{\circ} \mathrm{C}$ with hydrogen peroxide. Free fatty acids were precipitated with magnesium sulphate prior to reading the absorbance at $340 \mathrm{~nm}$. Standards $(25.0,20.0,10.0,5.0,2.5,1.25 \mathrm{mmol}$ $\mathrm{l}^{-1}$ purified triolein; Sigma 405-10) were run with each assay to assess precision of the method. All samples were run in a single assay and the intra-assay coefficient of variation was $5.7 \%$.

Total plasma protein was analyzed spectrophotometrically (Sigma Diagnostics Procedure 541). Samples were analyzed in a single assay. Precision of the assay was examined by running a standard in triplicate (Bovine protein; Sigma Diagnostics 540-10) at 3 concentrations: $\left(2.5,5.0\right.$ and $\left.10.0 \mathrm{~g} \mathrm{dl}^{-1}\right)$. Briefly, $20 \mu \mathrm{l}$ of plasma or standard was added to $1.0 \mathrm{ml}$ of reagent, incubated at $25^{\circ} \mathrm{C}$ for $10 \mathrm{~min}$ prior to recording absorbance at $540 \mathrm{~nm}$. Values were obtained by using the following formula: absorbance (sample) $\times 5$ (concentration of standard) / absorbance (standard). The average intra-assay coefficient of variation was $7.1 \%$.

Radioimmunoassay. Plasma samples from turtles were analyzed by a specific radioimmunoassay (RIA) for corticosterone and testosterone, similar to that used in previous studies (Jessop et al. 1999a,b). A $200 \mu \mathrm{l}$ aliquot of plasma was extracted twice with $3 \mathrm{ml}$ of diethylether, vortexed for $1 \mathrm{~min}$ and centrifuged at $1120 \times g$ for $5 \mathrm{~min}$. The organic phase was pipetted into a $16 \times 100 \mathrm{~mm}$ disposable glass culture tube and placed into a $37^{\circ} \mathrm{C}$ test-tube heater and evaporated to dryness before $0.75 \mathrm{ml}$ Tris buffered saline, $\mathrm{pH} 7.0$, was added. Duplicate samples were incubated overnight at $4{ }^{\circ} \mathrm{C}$ with tritiated corticosterone or testosterone (Dupont) and corticosterone or testosterone antibody (Endocrine Sciences). Antibody-bound steroid was separated from free steroid using a charcoal/dextran solution (1.25/ $0.125 \%)$. The antibody bound steroid was decanted into poly-Q vials (Beckman Scientific) containing $4 \mathrm{ml}$ aqueous based scintillant (Redisafe, Beckman Scientific) and counted on a Beckman LS6000 scintillation counter. A standard curve for corticosterone and testosterone (with 1000,

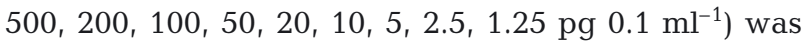

analyzed with each run of unknown plasma samples. A best fit non-linear equation was derived for each hormone standard curve using Curve Fit 2.1, enabling calculation of hormone levels for each unknown plasma sample. Mean extraction efficiency for corticosterone and testosterone was $92.4 \%$ and $91.9 \%$, respectively, as determined by recovery of tritiated label added to samples prior to adding diethylether. The average inter- and intra-assay coefficient of variation was $11.44 \%$ and $8.45 \%$ for corticosterone, and $13.23 \%$ and $10.35 \%$ for testosterone, respectively.

Statistical analysis. Statistics were performed using either Statistica (Kernel, release 5.5) or Sigma Stat (Jandel Scientific). All analyses were performed at a level of significance of $\mathrm{p}<0.05$; we report the group means in the text as the mean \pm SE. To prevent violation of the assumption of independence, a single blood sample was taken from each individual male captured in the field. Data were log transformed prior to analysis to meet the assumptions of parametric tests (normality Shapiro-Wilks p > 0.05). Statistical differences between reproductive groups were evaluated using unbalanced type III 1- and 2-way ANOVA, and post-hoc tests were calculated using Tukey unequal N HSD tests. For comparisons between 2 groups, a $t$-test was used.

Data used for results are represented by randomly measuring individuals in the population over time (i.e. every plasma sample is independent of one another). We assume that this population trend reflects what occurs in each individual male over the breeding season. For this species, this type of random sampling is the most appropriate procedure given the difficulty of recapturing individuals over time, which limits the use of a repeated measures approach. In this study there is considerable variation in sample size between data sets. This again is a result of logistical factors resulting in some turtles being blood sampled but not brought back to shore and weighed to provide body condition data. In addition, as hormone analysis was the priority for the majority of plasma samples, there were, in some cases, insufficient plasma to run both endocrine and plasma metabolite assays (as was the case for samples obtained in November). The hormone results presented here are data recast from an earlier behavioural study (Jessop et al. 1999b), but assessed with previously unanalyzed covariates.

\section{RESULTS}

There were significant interactions between male reproductive status and body condition from foraging through to the mid-late courtship period (2-way ANOVA: $F_{3,150}=3.519, \mathrm{p}=0.016$ ) (Fig. 1). Prior to migration (August), while male turtles were still forag- 
ing, the body condition index (BCI) of breeding male turtles ( $\mathrm{BCI}=4.75 \pm 1.96$ ) was greater (but not significantly so) than non-breeding males (BCI $=2.45 \pm 1.46)$. However, when breeding males were sampled sequentially through the mid- to late courtship period, their body condition decreased significantly into negative values, and by November the condition of breeding males $(\mathrm{BCI}=-6.18 \pm 2.57)$ was significantly below that of non-breeding males $(\mathrm{BCI}=0.31 \pm 3.39)$ (2-way ANOVA: $F_{1,150}=6.31, \mathrm{p}=0.013$ ). Non-breeding males exhibited no difference in body condition from August until early November.

In breeding males, levels of plasma triglyceride declined significantly from August (pre-migration) throughout the courtship period (1-way ANOVA: $F_{2,43}=20.566, \mathrm{p}<0.001$, Fig. 2). During August, plasma levels of triglycerides were significantly greater in breeding males $\left(2.41 \pm 0.21 \mathrm{mg} \mathrm{d} \mathrm{l}^{-1}\right)$ than non-breeding males $\left(0.53 \pm 0.08 \mathrm{mg} \mathrm{d} \mathrm{l}^{-1}\right)\left(t\right.$-test: $t_{1,13}=6.19, \mathrm{p}<$ $0.001)$. However, at the end of October, plasma triglyceride levels in breeding males $\left(0.77 \pm 0.10 \mathrm{mg} \mathrm{d} \mathrm{l}^{-1}\right)$ were similar to those measured in non-breeding males $\left(0.62 \pm 0.13 \mathrm{mg} \mathrm{d} \mathrm{l}^{-1}\right)\left(t\right.$-test: $\left.t_{1,20}=0.90, \mathrm{p}>0.05\right)$. In addition, there was no significant difference in plasma

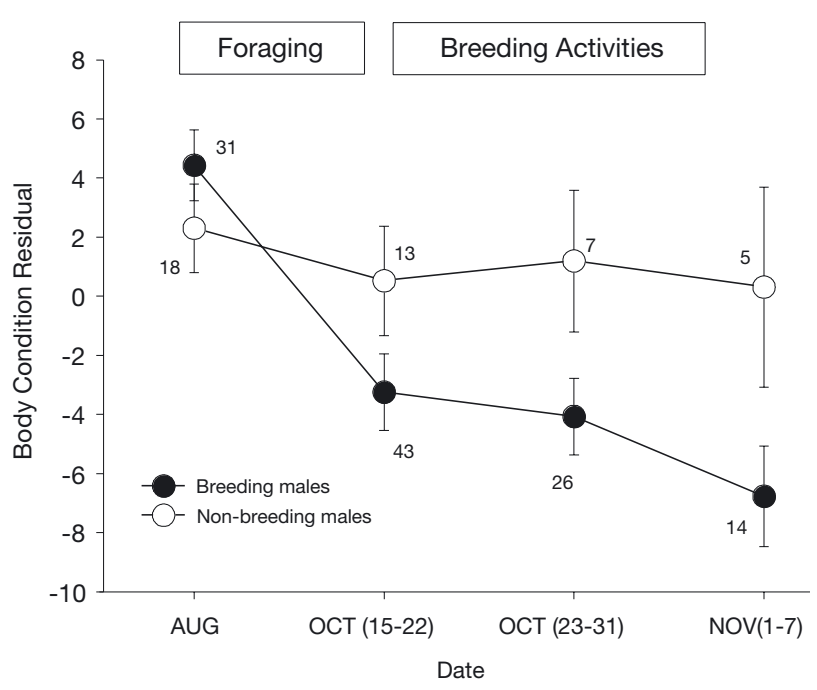

Fig. 1. Chelonia mydas. Changes in the body condition residuals (mean $\pm \mathrm{SE}$ of the mean) of breeding male green turtles (๑) compared to non-breeding males (O). Sample size (n) is shown at each sampling period. Sampling was conducted in August, a foraging period where both breeding and nonbreeding adult male turtles are still feeding, and then again during mid-October (dates are enclosed in brackets), late October and early November, coinciding with male breeding activities. During breeding activities, male turtles have migrated from their foraging area to reproduce, and they exhibit reduced feeding. They overlap with the resident population of non-breeding male adults who continue to feed

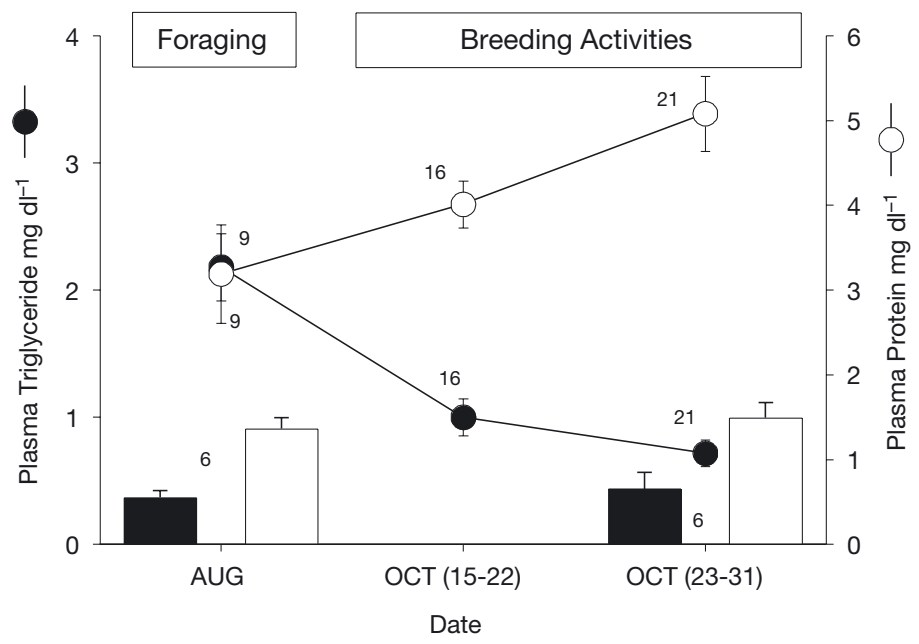

Fig. 2. Chelonia mydas. Profiles of the plasma metabolites (mean \pm SE of the mean), triglycerides (filled circles and bars) and total protein (open circles and bars) in breeding (line graph) and non-breeding (bar graph) male green turtles sampled prior to migration and then during breeding activities. Sample size (n) is shown at each sampling period

triglyceride levels measured between non-breeding males sampled in August and at the end of October ( $t$-test: $\left.t_{1,10}=0.58, \mathrm{p}>0.05\right)$.

In contrast, levels of plasma protein increased significantly from the pre-migratory levels through to courtship (1-way ANOVA: $F_{2,43}=6.149, \mathrm{p}<0.05$ ), as levels rose during late October. During August, plasma levels of protein were significantly greater in breeding males (3.38 $\pm 0.35 \mathrm{mg} \mathrm{d} \mathrm{l}^{-1}$ ) than non-breeding males $\left(1.36 \pm 0.13 \mathrm{mg} \mathrm{d} \mathrm{l}^{-1}\right)\left(t\right.$-test: $\left.t_{1,13}=4.58 \mathrm{p}<0.001\right)$. At the end of October, plasma protein levels in breeding males $\left(4.90 \pm 0.35 \mathrm{mg} \mathrm{d} \mathrm{l}^{-1}\right)$ were again significantly greater than those measured in non-breeding males $\left(1.49 \pm 0.18 \mathrm{mg} \mathrm{d} \mathrm{l}^{-1}\right)\left(t\right.$-test: $\left.t_{1,20}=5.78, \mathrm{p}<0.001\right)$. In addition, there was no significant difference in plasma protein levels measured between non-breeding males sampled in August and at the end of October ( $t$-test: $t_{1,10}=0.59, \mathrm{p}>0.05$ ).

Plasma testosterone levels decreased significantly from the pre-migratory period through to the mid- to late courtship period (2-way ANOVA: $F=2.619$, df $=$ $3,252, \mathrm{p}<0.001$, Fig. 3a.). Using Tukey's post-hoc method, it was evident that plasma testosterone levels during courtship were all significantly lower than the pre-migratory August level $(\mathrm{p}<0.05)$; however, during courtship, plasma testosterone levels declined gradually and were not statistically different from one another ( $p>0.05)$. At all sampling periods, testosterone levels measured for breeding males were significantly greater than non-breeding males 


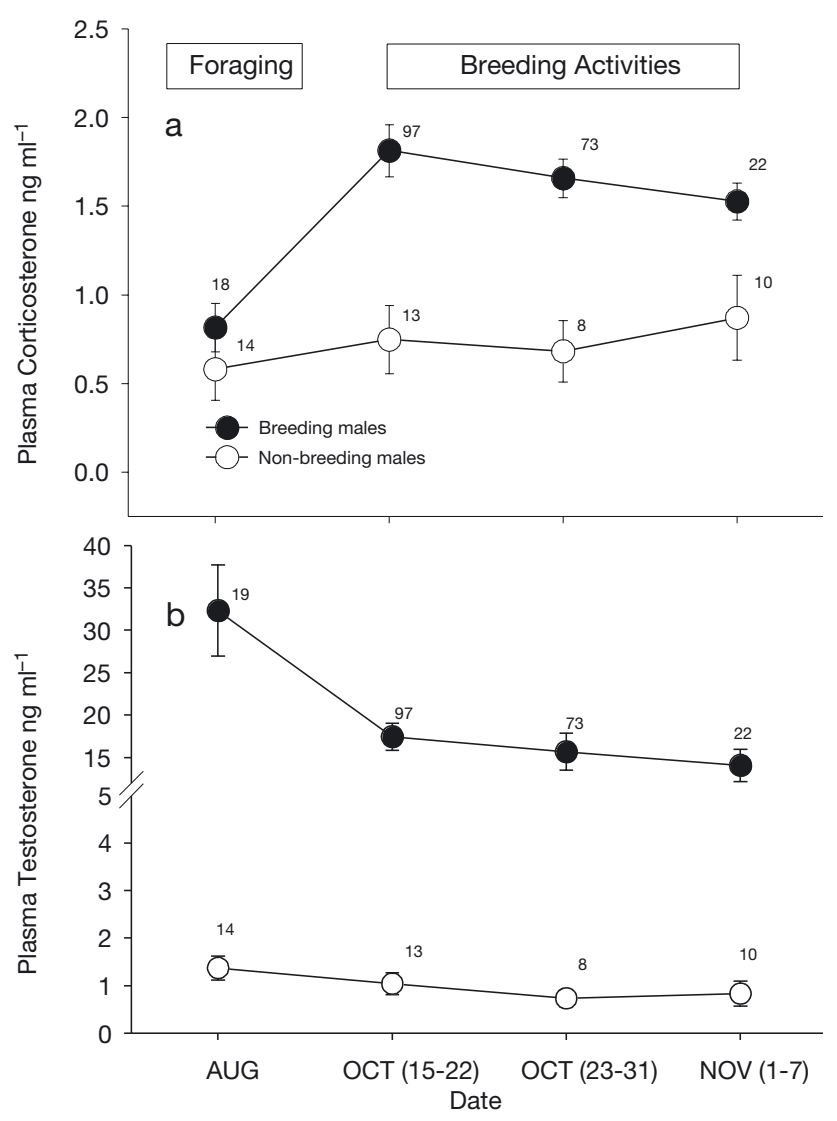

Fig. 3. Chelonia mydas. Changes in plasma concentrations (mean $\pm \mathrm{SE}$ of the mean) of corticosterone (a) and testosterone (b) in breeding (O) and non-breeding $(\mathrm{O})$ male turtles from August (pre-migration) through to the mid- to late courtship period during October and November. Sample size (n) is shown at each sampling period.

(2-way ANOVA: $F=147.667, \mathrm{df}=1,254, \mathrm{p}<0.001$, Fig. 3a). There was no significant difference in plasma testosterone across the 4 sampling periods in non-breeding males.

In breeding males, plasma corticosterone concentrations increased significantly from the pre-migration sampling period in August through to the midto late breeding period in October and November (2-way ANOVA: $F=20.517$, df $=3,252, \mathrm{p}<0.001$, Fig. 3b). The post-hoc multiple comparison method indicated that the pre-migration August levels of plasma corticosterone were significantly less ( $p<$ 0.05) than levels sampled during the mid- to late breeding period. Plasma corticosterone levels were significantly greater in breeding males compared to non-breeding males captured across the 4 sampling periods (2-way ANOVA: $F=13.9$, df $=1,254, \mathrm{p}<$ 0.001, Fig. 3b)

\section{DISCUSSION}

Our data indicate that in August, prior to migration and courtship, the body-condition index of breeding turtles was well above levels measured during courtship in October and November. Further, prior to migration the body condition index of breeding turtles was higher than that of non-breeding turtles. These data suggest that, like other vertebrates, including breeding females of this species, male green turtles accumulate significant body reserves prior to migration to provide the energy necessary for migration and reproduction (Kwan 1994, Hamann et al. 2002b, Schwilch et al. 2002). It is suspected that males accumulate significant body reserves, similar to female green turtles, by laying down adipose tissue (Kwan 1994). Like birds, the potential for hypertrophy of skeletal muscle in the pectoral region could also be an important protein reservoir for males, providing energy during the terminus of this life-history phase. Because of the energetically demanding nature of migration and reproduction, coupled with a reduction in feeding activity, males lost significant body condition (index decreased 2.34-fold) over the 2 to 3 mo combined migratory and breeding period. In November, we observed some breeding males in very poor body condition, including atrophy of pectoral and shoulder muscles, a depressed plastron, and a decrease in the girth of their tails. It is highly likely that these males had decreased bodycondition not only through loss of adipose tissue but also through reduction in muscle mass.

In concert with the large decrease in the body condition index, breeding males also exhibited energy metabolite changes associated with breeding activities. During the initial phase of their reproductive activities, breeding males exhibited a gradual decrease in plasma triglyceride levels until late October. In contrast, during this time, plasma protein levels significantly increased above pre-migration levels, particularly during late October. During August, breeding males had significantly elevated levels of both plasma triglyceride and total protein compared to non-breeding males. These differences in blood profiles prior to breeding allude to preparatory changes necessary to undertake breeding activities in the subsequent months. Female green turtles preparing to breed also exhibit significantly increased plasma triglyceride levels compared to adult females that are unable to reproduce in the subsequent nesting season (Hamann et al. 2002b). Non-breeding males sampled during August and late October exhibited no variation in plasma metabolites, a feature that likely reflects their normal feeding behaviour coupled with the absence of high energy expenditure, associated with reproductive activities during this period of the year. 
Further, the distinct changes in plasma lipid and protein profiles could indicate that breeding males exhibit similar patterns of energy resource partitioning and utilization during migratory activity and fasting periods as those exhibited by other vertebrates, such as birds, during endurance flights and incubation (Cherel et al. 1988a, Bauchinger \& Biebach 1998, Jenni \& Jenni-Eiermann 1998). It appears that male green turtles may initially utilize lipid reserves to fuel the migration and courtship phases before there is a marked increase in plasma levels of protein. This inverse transition in the levels of plasma triglyceride and plasma protein suggests that male green turtles, like other vertebrates, utilize a threshold of body condition, or a level of minimum adiposity, that when reached induces a metabolic shift increasing protein catabolism to supplement a decreasing lipid metabolism as a substrate for energy requirements (Cherel et al. 1988a, Schwilch et al. 2002). It is possible that the poor body condition of males arises first as a consequence of the depletion of fat reserves and subsequently due to atrophy of their skeletal muscle. Further research is necessary to determine whether, during the later phases of reproduction, skeletal muscle is providing the predominant energy source for maintenance until males resume significant feeding activities post reproduction. A similar profile of metabolite use is observed in breeding female green turtles where plasma triglyceride concentrations decrease towards the end of the nesting season, and plasma protein concentrations increase (Hamann et al. 2002b). This implies that both sexes utilise a metabolic shift towards protein catabolism to provide energy over their prolonged breeding seasons.

Plasma corticosterone concentrations increased in breeding males following migration, and remained elevated above levels measured in non-breeding males throughout the October/November breeding period. Elevation of basal plasma corticosterone levels both immediately prior to, and during, migration or reproduction has been documented in several species (Piersma et al. 2000, Landys-Ciannelli et al. 2002). It is currently thought to be necessary for mobilizing resources during, or in preparation for, periods of heightened energetic demands (Holberton et al. 1996, Holberton 1999, Jenni et al. 2000, Piersma et al. 2000). However, male penguins and female sea turtles tend to exhibit a contrasting pattern. Male penguins that undergo a prolonged fast during breeding, similar to that undertaken by male green turtles, suppressed their plasma corticosterone levels during the initial $2 / 3$ of their fasting, before elevating the levels in the final phase (Cherel et al. 1988c). In contrast to male green turtles, female sea turtles at the completion of the nesting season typically have decreased levels of plasma corticosterone (Whittier et al. 1997, Rostal et al. 2001,
Hamann et al. 2002a). Variation in patterns of corticosterone during migration and/or fasting could alter depending on the energetic context of the life-history phenomena. Breeding activities in males could be viewed as a high-energy-output fasting period, as males tend to maintain high physical activity during their breeding period. In contrast, female green turtles are relatively inactive, except for intermittent bouts of nesting activity, and thus undertake a more low energy and sustained fast. Subsequently, differences in daily energy usage could reflect different corticosterone patterns during the inter-migratory reproductive phases of breeding male and female green turtles. However, differences in corticosterone profiles between the sexes may also reflect hormonal requirements, underpinning reproduction in addition to energetic requirements.

Determining whether the elevation of corticosterone during the migratory/breeding phase is a result of purely metabolic adjustments is confounded by the fact that many reptiles, during reproduction, also exhibit increased elevations of corticosterone in the absence of migratory activities (Moore \& Jessop 2003). It is possible that as migration and reproduction both necessitate increased metabolic requirements, corticosterone acts synergistically in facilitating energy requirements for both activities.

Plasma testosterone levels were highest in August (winter) when males were still resident on their feeding grounds and still had to migrate and participate in reproductive activities. When males were sampled during the spring breeding phase between October and November, there was a conspicuous decrease in plasma testosterone. This pattern of temporal testosterone change is common amongst most sea turtles species, and is known as a prenuptial testosterone cycle in which plasma testosterone peaks during winter, inducing testicular recrudescence and spermatogenesis (Licht et al. 1985, Wibbels et al. 1990, Owens 1997 , Rostal et al. 1998). Once breeding activities begin in spring, plasma testosterone declines, reaching a nadir in late summer and early autumn, and will not increase again until the individual has obtained enough resources to undertake reproduction. While testosterone is likely to have a major role regulating reproductive physiology and, possibly, reproductive behaviors in male green turtles during the vernal breeding activities (Licht et al. 1985, Jessop et al. 1999b), it is not yet known how this steroid could directly influence overall body condition and metabolite changes during this period. Given that testosterone is a key anabolic steroid capable of causing hypertrophy of skeletal muscle, this hormone could be involved in pre-migratory body changes that lead to increased pectoral and shoulder muscle mass that facilitates swimming activities during 
migration and reproduction. Before migration, several bird species enlarge their pectoral muscles to increase flight performance (Fry et al. 1972, Driedzic et al. 1993, Dietz et al. 1999). The decreased body condition and elevated plasma protein levels found during the later phases of the breeding period, associated with declining levels of plasma testosterone, may indicate that reduced testosterone levels facilitate catabolism of muscle to provide energy at the later stage of the migratory breeding period. In birds, several tissues, including the breast muscles, digestive organs, skin and the liver may be catabolised to fuel the later phases of migration (Åkesson et al. 1992, Biebach 1998, Battley et al. 2000). In other animals undertaking fasting periods, such as penguins, a threshold of body mass is eventually reached, which triggers animals to begin feeding and abandon reproduction (Cherel et al. 1988b, Robin et al. 1998, Jenni et al. 2000). Limited data suggest that female green and hawksbill sea turtles do not show a significant decrease in body condition at the completion of the nesting season (Dobbs et al. 1999, Hamann 2002, but see Hays et al. 2002). It would seem likely that for male turtles some minimum threshold of body condition would be an important stimulus, along with a progressive reduction in receptive females, to induce male turtles to become refractory, cease reproduction and bring on a return migration to feeding grounds. In a previous study of male green turtles, it was evident that the individual body condition of a breeding male was associated with physiological responses to stress (Jessop et al. 2002). In particular, it was evident that males in poor body condition exhibited greater endocrine stress responses compared to males in good condition. It would be interesting to investigate whether the relationship between body condition status and physiology extended to other aspects of reproduction. For example, does the body condition of an individual male influence the behavioral tactics used to procure females during the courtship period? Is it possible that the individual capacity of a male green turtle to accumulate body reserves prior to commencing migration and breeding activities influences the reproductive strategies employed to achieve reproductive success? Males could vary high and low energy reproductive behaviors according to their overall energetic condition at different times throughout the breeding period. Hays et al. (2001) documented that breeding male green turtles at Ascension Island progressively decreased levels of activity as the breeding season progressed. This finding could imply that decreasing energetic condition (as seen in this study) influences reproductive activities.

In summary, this study investigated body condition, plasma metabolite and endocrinal changes occurring just prior to migration up until the mid- to late breeding period. Our data indicated that like many vertebrates with similar life-history events, male green turtles exhibit a significant reduction in body condition during breeding. In addition, plasma metabolites indicated that plasma triglycerides were elevated, perhaps indicating that male green turtles rely on lipid reserves prior to supplementing energy requirements with increased protein catabolism. Overall, migration and courtship appears to be a period of high-energy fasting for male green turtles, and the body and physiological changes appear to be similar to those that occur in other vertebrates that migrate and undertake periods of fasting. Future studies are required to clarify fuel use and metabolic requirements during this life-history event in male green turtles, and to examine phenotypic plasticity in behavioral reproductive tactics with respect to differences in an individual's energetic status.

Acknowledgements. We thank the many researchers and volunteers involved in the field work undertaken for this study, in particular D. Limpus, J. and C. Parmenter. J. Sumner generously provided comments and proofing on this manuscript. Logistical support for this study was provided by the Queensland Parks and Wildlife Service and the Great Barrier Reef Marine Park Management Authority. Support for laboratory analyses was generously provided by Dr J. Whittier at the University of Queensland. T.S.J. was supported by a Millennium post-doctoral fellowship from the Zoological Society of San Diego during preparation of this manuscript. This project was covered by the University of Queensland (ANAT/ 121/97/ARC) and a QPWS animal ethics permit.

\section{LITERATURE CITED}

Åkesson S, Karlsson L, Pettersson J, Walinder G (1992) Body composition and migration strategies: a comparison between Robins (Erithacus rubecula) from two stop-over sites in Sweden. Vogelwarte 36: 188-195

Battley PF, Piersma T, Dietz MW, Tang S, Dekinga A, Hulsman K (2000) Empirical evidence for differential organ reductions during trans-oceanic bird flight. Proc R Soc Lond B 267:191-195

Bauchinger U, Biebach H (1998) The role of protein during migration in passerine birds. Biol Conserv Fauna 102: 299-305

Belkhou R, Cherel Y, Heitz A, Robin JP, Le Maho Y (1991) Energy contributions of proteins and lipids during prolonged fasting in the rat. Nutr Res 11:365-374.

Biebach H (1998) Phenotypic organ flexibility in garden warblers Sylvia borin during long-distance migration. J Avian Biol 29:529-535

Booth J, Peters JA (1972) Behavioral studies on the green turtle (Chelonia mydas) in the sea. Anim Behav 20:808-812

Chaloupka M, Limpus C (2001) Trends in the abundance of sea turtles resident in Southern Great Barrier Reef waters. Biol Conserv 102:235-249

Cherel Y, Robin JP, Walch O, Karmann H, Netchitailo P, Le Maho Y (1988a) Fasting in king penguins 1. Hormonal and metabolic changes during breeding. Am J Physiol 254: R170-R177

Cherel Y, Leloup J, LeMaho Y (1988b) Fasting in king penguin II. Hormonal and metabolic changes during molt. Am J Physiol 254:R178-R184 
Cherel Y, Robin JP, Le Maho Y (1988c) Physiology and biochemistry of long term fasting in birds. Can J Zool 66: 159-166

Cogger H (1996) Retiles and amphibians of Australia. Reed Books, Sydney

Dietz MW, Piersma T, Dekinga A (1999) Body-building without power training: endogenously regulated pectoral muscle hypertrophy in confined shorebirds. J Exp Biol 202: 2831-2837

Driedzic WR, Crowe HL, Hicklin PW, Sephton DH (1993) Adaptations in pectoralis muscle, heart mass and energy metabolism during premigratory fattening in semipalmated sandpipers (Calidris pusilla). Can J Zool 71: 1602-1608

Dobbs KA, Miller JD, Limpus CJ, Landry Jr AM (1999) Hawksbill turtle, Eretmochelys imbricata, nesting at Milman Island, Northern Great Barrier Reef, Australia. Chel Conserv Biol 3:344-361

Fry CH, Ferguson-Lees IJ, Dowsett RJ (1972) Flight muscle hypertrophy and ecophysiological variation of yellow wagtail Motacilla flawa races at Lake Chad. J Zool Lond 167:293-306

Hamann M (2002) Reproductive cycles, interrenal gland function and lipid mobilisation in the green sea turtle Chelonia mydas. PhD dissertation, University of Queensland, Brisbane

Hamann M, Jessop TS, Limpus CJ, Whittier JM ( 2002a) Interactions among endocrinology, annual reproductive cycles and the nesting biology of the female green sea turtle. Mar Biol 140:823-830

Hamann M, Limpus CJ, Whittier JM (2002b) Patterns of lipid storage and mobilisation in the female green sea turtle (Chelonia mydas). J Comp Physiol B 172:485-493

Hays GC, Godley BJ, Broderick AC, Glen F, Nicholls WJ (2001) The movements and submergence behaviour of male green turtles at Ascension Island. Mar Biol 139: 395-399

Hays GC, Broderick AC, Glen F, Godley BJ (2002) Weight change associated with long-term fasting in a marine reptile: the case of green turtles (Chelonia mydas) at Ascension Island. Can J Zool 80:1299-1302

Holberton RL (1999) Changes in patterns of corticosterone secretion concurrent with migratory fattening in a neotropical migratory bird. Gen Comp Endocrinol 116:49-58

Holberton RL, Helmuth B, Wingfield JC (1996) The corticosterone stress response in gentoo (Pygoscelis papua) and king (Aptenodytes patagonicus) penguins during the nonfasting period. Condor 98:850-854

Jenni L, Jenni-Eiermann S (1998) Fuel supply and metabolic constraints in migrating birds. J Avian Biol 29:521-528

Jenni L, Jenni ES, Spina F, Schwabl H (2000) Regulation of protein breakdown and adrenocortical response to stress in birds during migratory flight. Am J Physiol 278: R1182R1189

Jessop TS, Limpus CJ, Whittier JM (1999a) Plasma steroid interactions during high-density green turtle nesting and associated disturbance. Gen Comp Endocrinol 115:90-100

Jessop TS, FitzSimmons NN, Limpus CJ, Whittier JM (1999b) Interactions between behavior and plasma steroids within the scramble mating system of the promiscuous green turtle, Chelonia mydas. Horm Behav 36: 86-97

Jessop TS, Knapp R, Whittier J, Limpus CJ (2002) Dynamic endocrine responses to stress: evidence for energetic constraints and status dependence in male green turtles. Gen Comp Endocrinol 126:59-67

Kwan D (1994) Fat reserves and reproduction in the green turtle, Chelonia mydas. Wildl Res 21:257-266
Landys-Ciannelli MM, Ramenofsky M, Piersma T, Jukema J, Wingfield JC (2002) Baseline and stress-induced plasma corticosterone during long-distance migration in the bartailed godwit, Limosa lapponica. Physiol Biochem Zool 75 101-110

Licht P, Wood JF, Wood FE (1985) Annual and diurnal cycles in plasma testosterone and thyroxine in the male green turtle Chelonia mydas. Gen Comp Endocrinol 57: 335-344

Limpus CJ (1993) The green turtle, Chelonia mydas in Queensland: breeding males in the southern Great Barrier Reef. Wildl Res 20:513-523

Limpus CJ, Reed P (1985) The green turtle, Chelonia mydas, in Queensland: a preliminary description of the population structure in a coral reef feeding ground. In: Grigg G, Shine $\mathrm{R}$, Ehmann $\mathrm{H}$ (eds) Biology of Australasian frogs and reptiles. Royal Zoological Society of New South Wales, Sydney, p 47-52

Limpus CJ, Couper PJ, Read MA (1994) The green turtle, Chelonia mydas, in Queensland: population structure in a warm temperate feeding area. Mem Qld Mus 35:139-154

Moore IT, Jessop TS (2003) Stress, reproduction, and adrenocortical modulation in amphibians and reptiles. Horm Behav 43: 39-47

Norman JA, Moritz C, Limpus CJ (1994) Mitochondrial DNA control region polymorphisms: genetic markers for ecological studies of marine turtles. Mol Ecol 3:363-373

Ortiz RM, Houser DS, Wade CE, Ortiz CL (2003) Hormonal changes associated with the transition between nursing and natural fasting in northern elephant seals (Mirounga angustirostris). Gen Comp Endocrinol 130:78-83

Owens DW (1997) Hormones in the life history of sea turtles. In: Lutz PL, Musick JA (eds) The biology of sea turtles. CRC Press, Boca Raton, FL, p 315-342

Piersma T, Reneerkens J, Ramenofsky M (2000) Baseline corticosterone peaks in shorebirds with maximal energy stores for migration: a general preparatory mechanism for rapid behavioral and metabolic transitions? Gen Comp Endocrinol 120:118-126

Robin JP, Boucontet L, Chillet P, Groscolas R (1998) Behavioral changes in fasting emperor penguins: evidence for a 'refeeding signal' linked to a metabolic shift. Am J Physiol 274: R746-R753

Rostal DC, Owens DW, Grumbles JS, MacKenzie DS, Amoss MS Jr (1998) Seasonal reproductive cycle of the kemp's ridley sea turtle (Lepidochelys kempi). Gen Comp Endocrinol 109:232-243

Rostal DC, Grumbles JS, Palmer KS, Lance VA, Spotila JR, Paladino FV (2001) Changes in gonadal and adrenal steroid levels in the leatherback sea turtle (Dermochelys coriacea) during the nesting cycle. Gen Comp Endocrinol 122:139-147

Schwilch R, Grattarola A, Spina F, Jenni L (2002) Protein loss during long-distance migratory flight in passerine birds: adaptation and constraint. J Exp Biol 205:687-695

Whittier JM, Corrie F, Limpus CJ (1997) Plasma steroid profiles in nesting loggerhead turtles (Caretta caretta) in Queensland, Australia: relationships to nesting episode and season. Gen Comp Endocrinol 106:39-47

Wibbels T, Owens DW, Limpus CJ, Reed PC, Amoss MS Jr (1990) Seasonal changes in serum gonadal steroids associated with migration, mating, and nesting in the loggerhead sea turtle (Caretta caretta). Gen Comp Endocrinol 79:154-164

Wingfield JC, Schwabl H, Mattocks Jr PW (1990) Endocrine mechanisms of migration. In: Gwinner E (ed) Bird migration: physiology and ecophysiology. Springer Verlag, Berlin

Submitted: August 25, 2003; Accepted: April 6, 2004

Proofs received from author(s): July 19, 2004 